\title{
BAJO LA SOMBRA DE LA COMUNA: SINDICALISMO Y REPUBLICANISMO EN LA BARCELONA DE 1871 ${ }^{1}$
}

\section{UNDER THE SHADOW OF THE PARIS COMMUNE: TRADE UNIONISM AND REPUBLICANISM IN 1871 BARCELONA}

\author{
Albert Garcia-Balañà \\ Universitat Pompeu Fabra
}

Recibido el 30-10-2015 y aceptado el 11-5-2016.

Resumen: El artículo pretende reabrir el debate historiográfico sobre el impacto de la Comuna de París en la España de 1871. Tras valiosas contribuciones que han subrayado la llegada de relatos y refugiados de la Comuna a la España en revolución, o las presiones de Thiers sobre el gabinete Serrano-Sagasta para la persecución de estos últimos, este artículo sostiene que fueron las concretas experiencias autóctonas de conflicto social y político las que resultaron fundamentales en la recepción española de la revolución parisina. Los debates parlamentarios de mayo de 1871 sobre la Comuna y la AIT nacieron de un específico episodio local de protesta obrera y movilización política plebeya. Un episodio que tuvo lugar en Barcelona durante los casi tres meses de vida de la Comuna. Y un episodio que, como tal, apenas ha recibido atención historiográfica. La paralización sindical de la mayor fábrica textil de España, la Fábrica Batlló, y la

1 Esta investigación tiene su origen en mi participación en el congreso Il y a 150 ans, l'Association Internationale des Travailleurs que tuvo lugar en París-Sorbonne en el verano de 2014. Quiero agradecer a Fabrice Bensimon, Quentin Deluermoz y Jeanne Moisand su invitación y su discusión de un breve y distinto borrador. Asimismo, quiero agradecer a Àngel Duarte, a Clara E. Lida y a Rafael Ruzafa su generosa lectura y comentario del primer borrador de este texto. Y a los/as evaluadores/as anónimos que lo leyeron para Historia Contemporánea, sus detalladas observaciones. Sobra decir que todo error es responsabilidad exclusivamente mía. 
mayor victoria electoral del Partido Republicano Democrático Federal (PRDF) tras la caída de Isabel II, confluyeron en la Barcelona de aquella primavera. La Comuna contribuyó a fundir ambos acontecimientos; a ella recurrió el patriciado barcelonés para desacreditarlos y hostigarlos, urgiendo la intervención de Sagasta. La ofensiva gubernamental contra sindicalistas y republicanos locales se cobijó bajo el manto del ataque de Versalles sobre París, exactamente durante los mismos días de mayo de 1871.

Palabras clave: Commune o Comuna de París (1871); Barcelona; Sexenio Democrático (1868-1874); Sindicalismo; Fábrica Batlló; Republicanismo; Asociación Internacional de Trabajadores (AIT).

\begin{abstract}
The article aims to take up again the historiographical debate about the impact of the Paris Commune in 1871 Spain. Researching beyond the well-known issue of Communard refugees in revolutionary Spain, the article argues that local experiences of social and political conflict were key to the Spanish reception of the Paris revolution. The May 1871 Spanish parliamentary lively debates on the Commune and the IWMA (or AIT) arose from a very specific local episode of workers' protest and popular political mobilization. The episode took place in Barcelona during the spring of 1871, while the Paris Commune was at its height. A challenging industrial strike that paralyzed Spain's largest cotton mill, the Batlló factory, and an unprecedented electoral victory by the Republican left-wing opposition of the Partido Republicano Democrático Federal (PRDF), overlapped then in Barcelona. The Commune, the article goes, contributed to merge both facts into one shared political experience. Barcelona ruling classes used the Commune transeuropean shadow to justify a simultaneous and hardline policy against trade unionists and Republicans. The Spanish Government final offensive against both local collective actors followed Versailles final attack on Communard Paris, exactly during the same days of late May 1871.
\end{abstract}

Key words: Paris Commune (1871); Barcelona; Spain's Sexenio Democrático (1868-1874); Trade Unionism; Batlló cotton mill; Republicanism; International Working Men's Association (IWMA or AIT). 
En mayo de 1871, en los días finales de la Comuna de París (18 de marzo a 28 de mayo de 1871), el Congreso de los Diputados vivió su primer gran debate sobre la llegada a España de la Asociación Internacional de Trabajadores (AIT). El debate nació de una interpelación al gobierno presentada por un diputado de la oposición republicana, Baldomero Lostau, en la que se acusaba al gobernador civil de la provincia de Barcelona - al gobierno pues - de «violar los artículos constitucionales que autorizan a los ciudadanos para reunirse y asociarse». Lostau dijo ser miembro de la Federación Regional Española (FRE) de la AIT, cuyo congreso fundacional se había celebrado en Barcelona (distrito electoral de Lostau) durante el verano anterior de 1870. En la sesión parlamentaria del 22 de mayo de 1871 el ministro de Gobernación, Práxedes M. Sagasta - hombre fuerte del primer gobierno bajo la nueva monarquía de Amadeo de Saboya-, replicó al catalán Lostau que la tensión que se vivía en Barcelona tenía mucho que ver con la presencia en la ciudad de Communards conectados con la AIT. Sagasta justificó la reciente expulsión de España de tres ciudadanos franceses por iniciativa del gobernador de Barcelona, por portar aquéllos «credenciales de la Commune de París» y actuar, además, como «principales agitadores de esa asociación, la Internacional». El ministro insistió en la imagen de «representantes de la Internacional que han atravesado las fronteras y se han repartido por el territorio español», y precisó que «donde la enfermedad se ha presentado con más gravedad es en las provincias catalanas y muy especialmente en Barcelona». ${ }^{2}$

En los días siguientes, los de la derrota de la Comuna parisina ante el ejército de Versalles, la prensa gubernamental publicó los nombres de los tres franceses deportados por su presunta conexión con París: Adolphe Royannez - blanquista recién derrotado en la brevísima Commune de Marsella (22 de marzo a 5 de abril de 1871), quien en 1868 había celebrado La Révolution en Espagne-, André Michel y Edmond

${ }^{2}$ Diario de las Sesiones de Cortes/Congreso [en adelante DSC/C], Legislatura de 1871, Sesión de 22 de Mayo de 1871, pp. 994-999 (presentación por Lostau de la proposición contra el gobierno y el gobernador de Barcelona de 19 de mayo de 1871) y pp. 9991.003 (Sagasta, la AIT y franceses en Barcelona). Sobre la Comuna y la AIT en el Parlamento en mayo de 1871: José Álvarez Junco, La Comuna en España, Siglo XXI de España, Madrid, 1971, pp. 39-48 y 85-99. 
Nodot. ${ }^{3}$ En los mismos días de mayo de 1871 un testimonio epistolar barcelonés corroboraba el alcance del muy reciente cruce de la frontera, el grado de eficacia de la hostilidad sagastina y, precisamente por todo ello, el reducido margen de maniobra de los Communards refugiados en Cataluña: «En esta Capital [Barcelona] llegan muchos Franceses de los emigrados, pero como saben que las disposiciones tomadas por el Gobierno es la persecución de ellos se albergan por los pueblos como son Sabadell, Manresa y otras poblaciones.» ${ }^{4}$ La política de vigilancia del gobernador civil, Bernardo Iglesias, era, a su vez, un aviso de otras persecuciones que estaban por venir. En los primeros días de junio Sagasta mandó instrucciones a todos los gobernadores otorgándoles «poderes ilimitados en orden a la represión de la Internacional», y la dirección o Consejo Federal de la FRE-AIT abandonó Madrid y se refugió en Lisboa. 5

\section{La Comuna en España: historiografías y perspectivas}

El pulso parlamentario entre Lostau y Sagasta de 22 de mayo de 1871 puede leerse como la síntesis de los dos grandes temas que, a propósito del impacto de la Comuna de París en España, han ocupado a la historiografía del último medio siglo. Por una parte, el tema de las influencias transnacionales en la formación y orientación de la FRE-AIT en la España del bienio 1870-1872. Y, en particular, el de la contribución a dichas influencias del exilio Communard, de lo que Clara E. Lida

${ }^{3}$ La Iberia (Diario Liberal) (Madrid), 24 de Mayo de 1871, p. 2 («...un emisario de la "Internacional" llamado Adolfo Royannes, gran orador de clubs, y otros dos auxiliares suyos...»); 23 de Mayo de 1871, p. 1 («Crónica Parlamentaria» y «La "Commune” vencida»). De Adolphe Royannez (1829-1880), director de La Voix du Peuple (Marsella) y colaborador del Journal de Toulouse en 1870 (véase el ejemplar de 15 de Septiembre de 1870, p. 1), puede consultarse Adolphe Royannez, La Révolution en Espagne, lettre d'un révolutionnaire français à un révolutionnaire espagnol, le citoyen A. Sarro Magallán... par ----, A. Le Chevalier, París, 1868.

${ }^{4}$ Biblioteca Víctor Balaguer (Vilanova i la Geltrú, Barcelona) [en adelante BVB], Epistolario de Víctor Balaguer, 7101873: carta de Miguel Mestres a Víctor Balaguer (Barcelona, ?? de Mayo de 1871).

5 Casimiro Martí, Orígenes del anarquismo en Barcelona, Teide, Barcelona, 1959, pp. 107-108 (nota 54); Josep Termes, Anarquismo y sindicalismo en España. La Primera Internacional (1864-1881), Crítica, Barcelona, 2000 [1965 y 1977], pp. 140-141. 
ha dado en llamar «comunalismo transpirenaico $»^{6}$, durante el año decisivo - para la naciente FRE - que transcurrió entre el verano de 1871 y el congreso de la AIT en La Haya de septiembre de 1872. Por otra parte, el tema de la alargada sombra de la experiencia y derrota de la Comuna proyectándose sobre los republicanismos hispanos en plena Revolución de 1868. Es decir, las discusiones y divisiones que la revolución local parisina y su aplastamiento militar suscitaron en las crecientes y plurales filas del Partido Republicano Democrático Federal (PRDF), discusiones y divisiones que habrían preparado el camino hacia la implosión de la breve República española de 1873. Ambos temas aparecen hoy indiscutiblemente entrelazados, como lo estaban ya, en parte, en el Baldomero Lostau de 1871, diputado a Cortes del PRDF y miembro de la FRE-AIT. Mérito de la perspicacia de la generación historiográfica de 1968 pero, también, de la primacía otorgada entonces al enfoque del impacto, a la centralidad analítica y narrativa de un polo emisor cuya luz - cuyas parisinas luces: federalismo, internacionalismo...- era «vista desde España» ${ }^{7}$.

Este artículo pretende subrayar un tercer tema implícito en el pulso entre Lostau y Sagasta y, con ello, interpelar a aquella generación historiográfica y a su legado, dialogar con aquel enfoque y sus resultados. A saber, subrayar el protagonismo de ciertos escenarios autóctonos y actores locales en la agitada coyuntura transeuropea de la primavera de 1871, y no sólo ni principalmente como entusiastas (o escépticos, o alarmados) receptores de ideas y vidas ajenas. El protagonismo, en este caso, de la ciudad de Barcelona y su hinterland, «donde - adujo Sagasta en descargo de los métodos del gobernador Iglesias - la enfermedad [de la presencia Communard y de la propaganda internacionalista] se ha presentado con más gravedad».

Sabemos de la existencia de redes de exiliados Communards en la España de 1871-1872 gracias a las investigaciones de Clara E. Lida. ${ }^{8}$ Y

${ }^{6}$ Clara E. Lida, «La Comuna de París y sus repercusiones: el caso español», en Guillermo Palacios y Erika Pani (coords.), El poder y la sangre: guerra, estado y nación en la década de 1860, El Colegio de México / Centro de Estudios Históricos, México D. F., 2014, pp. 183-195, p. 192.

7 María Victoria López-Cordón Cortezo, «La Comuna de París vista desde España», en José María Jover Zamora (dir.), El siglo XIX en España: doce estudios, Planeta, Barcelona, 1974, pp. 323-395.

8 Clara E. Lida, Anarquismo y revolución en la España del XIX, Siglo XXI de España, Madrid, 1972, pp. 186-201 («Ecos de la Comuna en España»), pp. 190-199. 
conocemos el destacado lugar que la ciudad de Barcelona desempeñó en dichas redes tras las prontas derrotas de las Comunas del Midi en marzo y abril de 1871. Lida encontró al ya citado Edmond Nodot, «oficial retirado de marina [y] redactor de una hoja radical y socialista en Perpignan o Marsella», en los despachos de un confidente de la policía francesa quien en el invierno de 1871-1872 daba cuenta de su reciente expulsión de España. ${ }^{9}$ Dos habrían sido las consecuencias de este exilio transpirenaico. En primer lugar, aquella primera oleada de hostigamiento contra la recién nacida FRE-AIT desatada por Sagasta a las puertas del verano de 1871. Oleada que respondería, en parte, a la presión diplomática de Thiers y su ministro Favre y, pues, a la consiguiente alarma transeuropea producida por y a propósito de París. ${ }^{10} \mathrm{Y}$ en segundo lugar, y más importante, esta pronta represión gubernativa habría abonado el terreno, a su manera, para un mayor protagonismo en España del bakuninismo y de su clandestina Alianza para la Democracia Socialista. El viaje del «bakuninista» Giuseppe Fanelli a Madrid y Barcelona en 1869, y los redoblados contactos con Ginebra y Lyon (no con Londres) del pequeño núcleo fundacional barcelonés durante $1870^{11}$, se verían completados por la atmósfera de 1871, todo lo cual habría propiciado el liderazgo sindical de unos pocos y pequeños grupos amparados por decisivas conexiones internacionales, altamente ideologizados, y dispuestos y preparados para la acción clandestina. El exilio temporal en Lisboa del Consejo Federal de la FRE-AIT en junio de 1871 sería, así, el pistoletazo de salida de la secuencia histórica de cristalización de un sindicalismo revolucionario por «antipolítico». Una secuencia pronto confirmada por la ilegalización formal de la FRE-AIT en el invierno de 1871-1872. Para Clara E. Lida, «los meses que transcurren entre el fin de la Comuna y el del levantamiento alcoyano [en julio de 1873] muestran que la FRE desarrolla consciente y cuidadosamente una estrategia que le permita transitar hacia la clandestinidad cuando las circunstancias gubernamentales así lo exigieran [...] siguiendo el modelo diseñado por la Alianza bakuninista»..$^{12}$

9 Clara E. Lida, Anarquismo y revolución..., p. 194.

10 Clara E. Lida, «Hacia la clandestinidad anarquista. De la Comuna de París a Alcoy, 1871-1874», Historia Social, 46 (2003), pp. 49-64, pp. 56-57.

${ }^{11}$ Clara E. Lida, Anarquismo y revolución..., pp. 191-192; Josep Termes, Anarquismo y sindicalismo..., pp. 134-148.

12 Clara E. Lida, «Hacia la clandestinidad anarquista...», p. 57. 
El otro gran tema historiográfico a propósito de los «ecos de la Comuna en España» (Lida), la cuestión de la recepción republicana de las Comunas francesas de 1870-1871, ha progresado fundamentalmente en dos direcciones. Una, la dirección de mostrar hasta qué punto el debate sobre la Comuna se incorporó, y contribuyó, a la división entre republicanos unitaristas y federales, y entre «benévolos»e «intransigentes» entre estos últimos. Esta división en las élites republicanas pudo constatarse en la oposición de sólo 25 de los 48 diputados del PRDF a la condena que de los refugiados franceses hicieron las Cortes en los últimos días de mayo de 1871. El radicalismo social Communard, y la batalla - y derrota - sin cuartel parisina de finales de mayo, iban a fracturar al PRDF en mayor proporción de lo que la defensa del municipalismo democrático francés lo había unido meses atrás. Los libros, ya clásicos, de C. A. M. Hennessy y José Álvarez Junco arrojan no poca luz sobre ambos momentos. ${ }^{13}$

Una segunda y más reciente dirección ha rastreado el cómo pudo afectar la Comuna, y su aplastamiento militar, a las bases del republicanismo español. Marie-Angèle Orobon ha documentado, por ejemplo, la centralidad de un renovado concepto de pueblo en la retórica de mitificación federal de la Comuna. Concepto clave en el lenguaje político de la tradición demócrata y republicana española, el pueblo incorporó entonces sus primeros significados abiertamente clasistas, en el sentido de antiburgueses, mutación que iba a ocurrir lenta y disputadamente. ${ }^{14} \mathrm{La}$ abundante publicística de hoja suelta, y particularmente los martirologios laicos e ilustrados que circularon tras la «Semaine Sanglante» (21 a 28 de mayo de 1871), acreditan la existencia de un consumo genuinamente popular, por

13 C. A. M. Hennessy, The Federal Republic in Spain. Pi y Margall and the Federal Republican Movement, 1868-1874, Clarendon Press, Oxford (UK), 1962, pp. 143-159; José Álvarez Junco, La Comuna en España, pp. 2-5, 31-38 y 125-154.

14 Marie-Angèle Orobon, «Años 1870 y 1871 en Francia y en España: a vueltas con el pueblo», Historia Contemporánea, 28 (2004), pp. 147-156, p. 153 («...se consagra en aquella coyuntura en España, y al calor de los acontecimientos parisinos, la antonimia pueblo/burguesía...»); Marie-Angèle Orobon, La Commune de Paris en Espagne, de la presse au roman populaire, Tesis Doctoral, Université de Paris III, 1995. Me he ocupado de ésta y otras mutaciones de significado en los lenguajes del obrerismo barcelonés, antes y después de 1868, en Albert Garcia Balañà, « «El verdadero productor»: lenguaje y experiencia en la formación de las culturas políticas obreras», en María Cruz Romeo y María Sierra (eds.), La España liberal, 1833-1874 [vol. II de Historia de las culturas políticas en España y América Latina], Marcial Pons / Prensas Universitarias de Zatagoza, Madrid / Zaragoza, 2014, pp. 217-251. 
ejemplo en la Barcelona de $1871 .{ }^{15}$ Por su parte, Antonio López Estudillo y Pere Gabriel han coincidido, en trabajos distintos, en que el aplastamiento por Thiers y Gambetta de la Comuna, y el disenso sobre ella en el seno del PRDF, pudo favorecer el acercamiento de no pocas bases del republicanismo autóctono hacia el naciente internacionalismo. En palabras de López Estudillo, «la Comuna contribuyó a radicalizar a amplios segmentos del federalismo, buena parte del cual tomaría a la Internacional como referente e ingresó en sus filas sin abandonar su politicismo». ${ }^{16}$ Una tesis que parecen avalar la cronología y los números: los poco más de 2.000 cotizantes a la FRE-AIT de principios de 1871 («cuatro quintas partes de ellos de la federación de Barcelona») se habían convertido en más de 10.000 en abril de 1872, a pesar de la represión desatada sobre los líderes locales conectados con Ginebra (o con Londres), de la intermitente prohibición legal, y de la gestación de la traumática ruptura entre la mayoría bakuninista y la minoría marxista en la reducida dirección «regional» española. ${ }^{17}$ Pere Gabriel se ha referido a la revolución parisina como espoleta de «una cierta separación del obrerismo más militante con respecto al republicanismo pues podía acusarse a los republicanos franceses de ser un régimen burgués represor de la Comuna», lo que habría alimentado - también en Cataluña - un «anarcosindicalismo cada vez más fuerte». ${ }^{18}$ Baldomero Lostau, candidato «político» a representante de la FRE en el congreso de la AIT en La Haya (1872), obtuvo un puñado de votos en Cataluña pero tuvo que ceder el paso a otros cuatro delegados, todos «antipolíticos» aupados por una dirección ya bakuninista. ${ }^{19}$

15 Algunos ejemplos: Proceso de la Commune de París: relación completa y detallada de todas las causas que se están siguiendo en el consejo de guerra instalado en Versalles..., I. López editor, Barcelona, 1871; Fusilamientos en Francia en el campo de Satory del sargento Bougeois y los ciudadanos Ferre y Rossell, miembros de la Commune de París..., Narciso Ramírez, Barcelona, 1871; «Celebridades de la Commune de París», La Campana de Gràcia (Barcelona), 4 de Junio de 1871, pp. 1-4.

16 Antonio López Estudillo, «El anarquismo español decimonónico», Ayer, 45 (2002), pp. 73-104,p. 87.

17 Antonio López Estudillo, «El anarquismo español...», pp. 86-89.

18 Pere Gabriel, «Visibilitats polítiques i vertebració social del món obrer i popular de Barcelona, 1868-1874», Barcelona Quaderns d'Història, 15 (2009), pp. 53-77, p. 75 [traduzco las citas del catalán original]. Una tesis semejante en Josep Termes, Anarquismo y sindicalismo..., pp. 178-180.

19 Antonio López Estudillo, «El anarquismo español...», pp. 89-90; Josep Termes, Anarquismo y sindicalismo..., pp. 165-169. 
Este artículo propone una nueva aproximación a la primavera de 1871 en España que no dé por sentada la primacía, analítica y narrativa, de una perspectiva Communard-céntrica. Que no dé por sentado que Sagasta atendía, sólo o fundamentalmente, a las demandas de Thiers cuando puso el foco y la alarma sobre los refugiados franceses en Cataluña. Que no dé por sentado que la persecución contra la FRE-AIT de mayo y junio de 1871 obedeció, ante todo, a la alargada sombra de la Comuna, a una represión preventiva por transeuropea. O que no dé por sentado que las élites y las bases del PRDF supieron - y discutieron - de la Comuna por unas mismas vías y fuentes, en lugar de a través de experiencias de mediación experiencias de mediación social y territorialmente específicas. Se trata, pues, de ver a quienes veían la Comuna «desde España» en el preciso momento en el que volvían la vista hacia París, mientras todo acontecía. Y de fijarse, sobre todo, en las concretas circunstancias, en las particulares experiencias desde las que la miraban (a menudo de reojo, y tenían - como mostraré- buenas razones para ello).

El artículo sostiene que la política de fuerza del gabinete Serrano-Sagasta en mayo y junio de 1871 fue una respuesta a un doble episodio ocurrido en Barcelona aquella misma primavera, y algo más que un «eco» de la Comuna en España. Doble episodio pues en los mismos días de la revolución parisina confluyeron en la ciudad, además de los exiliados Cотmunards, una conflictiva y significativa huelga obrera y el mayor éxito electoral del PRDF en la España post-1868. La huelga que paralizó la primera fábrica textil del país durante los casi tres meses de la Comuna resultó decisiva para la integración del sindicalismo algodonero en la FRE; sin embargo, los agravios y argumentos obreros que la motivaron venían de muy atrás, y en ningún caso el grueso de su empuje y legitimidad procedía de la recién llegada AIT. Lo cual no significa que ésta no espolease a los huelguistas y redoblase la alarma de patronos y propietarios. También días después de la toma de París por la Garde Nationale, el PRDF ganó de calle las elecciones provinciales y con éstas la Diputación de Barcelona. La más poderosa institución que gobernaron los republicanos federales desde la caída de Isabel II iba a sostener un pulso con el gobierno monárquico, también a propósito de aquella huelga y de la coartada anti-Communard para acabar con ella. Ambos episodios han merecido poca atención historiográfica y siempre tratados por separado. No los deslindaron, en cambio, Lostau y Sagasta en su forcejeo parlamentario de finales de mayo. Ni lo hicieron, como mostraré, tantos otros contemporáneos, quienes los vivieron - desde el temor o la esperanza - como fragmentos de una única y sincrónica ex- 
periencia. La correspondencia privada e inédita usada en este artículo, procedente principalmente del archivo personal de Víctor Balaguer, muestra que las élites amadeístas barcelonesas urgieron a actuar al ministerio Sagasta con tanto o más apremio que el desplegado por el gobierno de Versalles. El vínculo entre sindicalismo algodonero y cultura política demócratarepublicana era fuerte y muy duradero en Barcelona a la altura de 1871. En tales circunstancias, la Comuna podía trazar, en su brevísimo triunfo, un horizonte de renovada colaboración para ambos actores colectivos barceloneses. O convertirse en un espantajo - y con más razón tras los combates parisinos de mayo - al servicio de una élite local y regional a la defensiva ante aquellos mismos actores, a los que temía porque sus reservas de fuerza estaban precisamente en Barcelona y no en París.

\section{Barcelona, primavera de 1871: huelga obrera y sindicalismo de oficio}

El ministro Sagasta arrancó su intervención parlamentaria del 22 de mayo de 1871 con la lectura de un telegrama del gobernador de Barcelona, Bernardo Iglesias, «fechado a las dos y media de esta tarde», cuyo inicio rezaba: «Tengo la satisfacción de saludar a V[uestra] E[xcelencia] desde la gran fábrica de los Sres. Batlló Hermanos, que hoy ha vuelto a abrirse al trabajo después de tres meses de paralización. Este fausto acontecimiento, tan anhelado por la culta Barcelona, es de la más ventajosa trascendencia para el crédito industrial de España, para el bienestar de las clases obreras, y para el robustecimiento del orden público.» Sagasta justificó la expulsión de los tres Communards franceses, supuestos «principales agitadores de la Internacional», por su contribución a la huelga obrera que había bloqueado la fábrica barcelonesa de Batlló precisamente durante los setenta días de la Comuna parisina y aún antes, desde los últimos días de febrero. ${ }^{20}$ Además, y como parte de la misma represión, el gobernador Iglesias mandó detener a Gaspar Sentiñón, médico recién establecido en Barcelona tras años en Viena, delegado en el congreso de la AIT en Basilea (otoño de 1869) y desde entonces íntimo de Bakunin. Sen-

20 DSC/C, Legislatura de 1871, Sesión de 22 de Mayo de 1871, pp. 999-1.000 (Sagasta sobre el telegrama del gobernador Iglesias) y pp. 1.002-1.003 (Sagasta sobre los tres franceses expulsados y la AIT); ver también La Iberia (Madrid), 24 de Mayo de 1871, p. 2 (defensa del gobernador Iglesias, «firme en su empeño de conjurar los elementos de incesante desorden que se reunían en Barcelona»). 
tiñón y el periódico obrerista que administraba en Barcelona, La Federación, fueron acusados de dirigir la huelga así como de circular por toda la ciudad un Manifiesto de Algunos Partidarios de la Commune a los Poderosos de la Tierra. ${ }^{21} \mathrm{El}$ gobierno atribuyó la huelga local a actores y redes transnacionales cuyos principales nudos se hallaban lejos de Barcelona (y de España). Y la prensa gubernamental en Madrid no dudó en presentar, a principios de junio, el contundente final de la huelga como parte de un paisaje global de derrota de la Comuna. ${ }^{22}$

No faltan las fuentes que confirman el notable impacto de la huelga de la fábrica Batlló en la vida barcelonesa de 1871, y el rápido arraigo de su lectura en clave transnacional e internacionalista también en Madrid. Fuentes fechadas, sobre todo, tras los enfrentamientos entre decenas de huelguistas y fuerzas policiales de finales de marzo, durante los cuales fue atacado mortalmente uno de los mayordomos de la algodonería. Y durante los cuales el gobernador provincial tuvo «que pedir refuerzos a la tropa del ejército» - según La Iberia capitalina de 28 de marzo - ante «la actitud de los grupos que crecían por momentos [...] y el aviso de que querían detener su carruaje». ${ }^{23}$ Finales de marzo, es decir, pocos días después de la proclamación de la Comuna de París, el 18 de marzo de 1871.

Con fecha domingo 26 de marzo de 1871 el alcalde del pueblo metropolitano de Les Corts, en cuyos límites se alzaba la fábrica, le decía en urgente nota al gobernador: «El cabo de caballería de la Guardia Civil de servicio en la fábrica de los Sres. Batlló me acaba de dar parte de haber sido herido de gravedad un operario de la expresada fábrica.» ${ }^{24} \mathrm{El}$ episo-

21 Véase Casimiro Martí, Orígenes del anarquismo..., p. 83 (nota 39); Anselmo Lorenzo / José Álvarez Junco, El proletariado militante (prólogo y notas de José Álvarez Junco), Alianza Editorial, Madrid, 1974, pp. 54 y 446 (nota 21). Sentiñón y la formación del núcleo bakuninista en la Barcelona de 1869-1870: Pere Gabriel, «Visibilitats polítiques...», pp. 73-74.

22 Un ejemplo en La Iberia (Madrid), 7 de Junio de 1871, p. 2 («Silencio espresivo» y «La fábrica de los Hermanos Batlló...»).

${ }_{23}$ La Iberia (Madrid), 28 de Marzo de 1871, p. 1 («Noticias particulares de Barcelona nos comunican que los obreros de aquella ciudad, excitados por los agentes de la Internacional,...»; según dicha crónica, el domingo 26 de marzo una concentración frente a la fábrica Batlló terminó con el ataque al mayordomo al que «causándole cuatro heridas, una de ella de gravedad, le arrastraron por las calles»); La Esperanza (Madrid), 4 de Abril de 1871, p. 1 («Ha fallecido el contramaestre de los Sres. Batlló que fue herido días atrás...»).

${ }^{24}$ Arxiu Municipal del Districte de Les Corts [en adelante AMDLC] (Barcelona), 7.3. Control de Població: vagues, revoltes...: comunicación del alcalde al Gobierno Civil (Les Corts, 26 de Marzo de 1871). 
dio habría terminado con la contundente intervención de «una compañía de cazadores, ocho caballos del ejército y otros ocho o diez de guardias civiles» que consiguieron «despejar [a] la multitud». ${ }^{25}$ La Iberia gubernamental acusaría en mayo a la oposición republicana, «a ese partido que a palma batiente saluda la aparición de la Commune», de reprender al nuevo gobernador de Barcelona, Iglesias, por tratar de poner coto «a los internacionalistas y al campo de sus violencias», por prevenir que se repitiese el «asaltar fábricas, asesinar a mayordomos y arrastrar sus cuerpos». ${ }^{26} \mathrm{La}$ Federación obrerista, en su versión de los hechos de primeros de abril, había reconocido implícitamente la muerte del mayordomo al reprochar a «la prensa» el haber «desfigurado las tristes ocurrencias habidas», pues «los periódicos no han consignado que a los huelguistas se les tiraron piedras desde el interior que hirieron a una mujer y a un niño; que una mujer recibió dos bayonetazos, y que un hombre fue herido por los disparos que se hicieron desde la fábrica por los mozos de escuadra que a su servicio tienen los hermanos Batlló». ${ }^{27}$ La vigilancia y presión de huelguistas y trabajadores sindicalizados sobre la minoría que había seguido trabajando, y el clima de cargada tensión, no habían cesado durante los meses de marzo y abril, según las comunicaciones dirigidas al Gobierno Civil. ${ }^{28}$

Para uno de los informantes en Barcelona del monárquico Progresista catalán Víctor Balaguer, entonces director general de Comunicaciones del gobierno Serrano-Sagasta y pronto Ministro de Ultramar, «lo de la Fábrica Batlló, la aparición de la Internacional que tantos disgustos ha de causar y tantas lágrimas hará caer, ha completado el cuadro para que los conservadores se alejen del gobierno [del nuevo rey Amadeo de Saboya], de manera, se lo aviso como buen liberal, [...] que si el gobierno no toma otra marcha más decidida y fuerte, los hombres liberales mañana votarán en Barcelona por los carlistas». ${ }^{29}$ Pocos días antes de esta misiva, el 30 de marzo, el cónsul italiano en Barcelona había escrito a Roma que en la ciudad «se observa en los disturbios provocados en la Fábrica Batlló la pro-

25 La Iberia (Madrid), 28 de Marzo de 1871, p. 1.

${ }^{26}$ La Iberia (Madrid), 17 de Mayo de 1871, p. 1 («No hace muchos días trasladábamos a nuestros lectores...»).

27 La Federación (Barcelona), 2 de Abril de 1871, p. 2 («El paro de Casa Batlló»).

28 AMDLC (Barcelona), 7.3. Control de Població: vagues, revoltes...: comunicaciones del alcalde de Les Corts al Gobierno Civil de 3 de Marzo de 1871, 13 de Marzo de 1871, 25 de Marzo de 1871, 26 de Marzo de 1871, 16 de Abril de 1871 y 17 de Abril de 1871.

${ }^{29}$ BVB, Epistolario de Víctor Balaguer, 7102901: carta sin firmar a Víctor Balaguer (Barcelona, ?? de Abril de 1871). 
paganda socialista de la Internacional». ${ }^{30}$ También el recién llegado y aún libre Gaspar Sentiñón compartía la misma mirada, él por supuesto desde el optimismo, en carta de 17 de abril a Nikolay Zhukovsky; según Nettlau la carta «habla del temor de la burguesía de que la Commune encuentre una repercusión en España, y del gobernador de Barcelona que ha sido reemplazado por otro [Bernardo Iglesias] dispuesto a suprimir las huelgas del momento por la fuerza». 31

La política de fuerza aplicada por el nuevo gobernador civil, Bernardo Iglesias, iba a frenar la temperatura del conflicto más allá de las paredes de Batlló, pero menos su percepción, sin duda alimentada por semanas de huelga y tensión en la ciudad. A finales de mayo, tras la reapertura gubernativa y policial de la fábrica, otro de los informantes a pie de obra de Víctor Balaguer le contaba en un castellano elemental por híbrido: «Sabrá V. que hace cuatro o cinco días que se a havierto la Fábrica de Batlló, y como ahora estoy en el 3er Distrito depende de mi demarcación, dándonos mucho trabajo y estamos muy propenso a haber un conflicto. Ace dos días que no sé como han salido vivos los individuos del Distrito pues antes de ayer han salido más de 100 hombres hechando pestes contra los agentes de O. P. y los trabajadores, y ayer sucedió lo mismo.» ${ }^{32} \mathrm{Y}$ fundía en una misma imagen lo viejo y lo nuevo, la protesta comunitaria protagonizada por mujeres en las calles del distrito y la aparición de la AIT: «Esta mañana [...] no hemos tenido más novedad que un gran griterío de mugeres que desde las ventanas nos llamaban asesinos»; «tocando la cuestión de la Fábrica Batlló parece que [...] ha pasado el mayor movimiento sin que por eso las mugeres dejen de escandalizar, que éstas lo hacen promovidas por la Internacional». .3

Dos factores parecen explicar, a simple vista, la percepción patricia de una decisiva influencia exterior en la huelga de Batlló, inseparable del binomio AIT-Comuna y de su circulación transnacional. En primer lugar, la condición emblemática de la fábrica Batlló en la Barcelona de 1871.

30 Citado en Casimiro Martí, Orígenes del anarquismo..., p. 107 (nota 53).

31 Max Nettlau, Miguel Bakunin, la Internacional y la Alianza en España, 1868-1873 [1925], p. 63 (citado en Casimiro Martí, Orígenes del anarquismo..., p. 107, nota 53).

${ }^{32}$ BVB, Epistolario de Víctor Balaguer, 7101733: carta de Miguel Mestres a Víctor Balaguer (Barcelona, 26 de Mayo de 1871).

${ }^{33}$ BVB, Epistolario de Víctor Balaguer, 7101733 y 7101873: cartas de Miguel Mestres a Víctor Balaguer (Barcelona, 26 de Mayo de 1871 y ?? de Mayo de 1871); ver también 7101896: carta de Miguel Mestres a Víctor Balaguer (Barcelona, 9 de Junio de 1871). 
Recién abierta en 1870, Batlló Hermanos era, simplemente, la mayor fábrica textil de España en los tempranos años setenta (y el mayor edificio civil en la Barcelona que se expandía más allá de las murallas apenas derribadas durante la década anterior). Concebida para emplear a más de 1.500 trabajadores en una «manzana» única del Ensanche barcelonés - única al unir cuatro de las «manzanas» convencionales diseñadas por Ildefons Cerdà - , los más de 50.000 husos de hilar algodón y más de 1.300 telares mecánicos de Batlló no tenían parangón en la industria catalana de entonces. ${ }^{34} \mathrm{Su}$ lejanía física de la Barcelona vieja y de su tradicional distrito algodonero en el Raval, su localización periurbana en los límites del pueblo de Les Corts, alimentarían desde el primer día su doble imagen de nuevo modelo patronal y de prevención y sospecha obreras. ${ }^{35}$

Y, en segundo lugar, el hecho de que fuese precisamente durante la huelga - y durante los primeros días de la Comuna-, en marzo de 1871, que el sindicato que la había convocado a finales de febrero, la ya federación de oficios Tres Clases de Vapor, ingresase en la AIT (aunque muchas de sus secciones locales lo harían más tarde o no lo harían nunca) ${ }^{36} \mathrm{~A}$ título de comparación, si los cotizantes a la FRE-AIT a principios de 1871 eran poco más de 2.000 , los miembros de las Tres Clases de Vapor (o Unión de Hiladores, Tejedores Mecánicos y Jornaleros) eran casi 9.000 en diciembre de 1870, todos ellos en la provincia de Barcelona (dividida en

34 Albert Garcia Balañà, La fabricació de la fàbrica. Treball i política a la Catalunya cotonera (1784-1874), Publicacions de l'Abadia de Montserrat, Barcelona, 2004, pp. 516517 (y nota 12); Carles Enrech, Indústria i ofici. Conflicte social i jerarquies obreres a la Catalunya tèxtil (1881-1923), Universitat Autònoma de Barcelona, Bellaterra, 2005, pp. 36-37. La modificación de la trama urbana de Cerdà para la ejecución del proyecto, un caso excepcional, en AMDLC (Barcelona), «Instal.lació Fàbrica» (1867-1870): «Ayuntamiento de Las Corts. Policía Urbana. Expediente sobre unión de cuatro manzanas en una en la zona de ensanche de Barcelona, promovido por los Sres. Batlló Hermanos y consiguiente construcción de una gran fábrica de hilados y tejidos...» (1867-1869).

${ }^{35}$ El municipio de Les Corts contaba con 828 habitantes en 1861 (de los cuales apenas 74 «jornaleros de fábrica»). La apertura de Batlló Hermanos en 1870 transformó su paisaje urbano y demográfico: 1.961 habitantes en 1877 (625 residentes en la Barriada de Batlló) y 4.760 habitantes en 1889, antes de su agregación definitiva al municipio de Barcelona. Tomo todos los datos de AMDLC (Barcelona), 9.1. Població: estadístiques generals i resums dels padrons (1857-1889).

36 Según La Federación (Barcelona), 26 de Marzo de 1871, p. 2; detalles en Miguel Izard, Industrialización y obrerismo. Las Tres Clases de Vapor (1869-1913), Ariel, Barcelona, 1973, pp. 114-115 (y notas 13 y 14). 
seis distritos con sus respectivas secciones locales). ${ }^{37}$ Gaspar Sentiñón no iba a sufrir en solitario su encierro en el castillo militar de Montjuïc desde finales de mayo y durante el verano de 1871. Lo acompañaría Climent Bové, «director» de las Tres Clases de Vapor, también detenido por el gobernador Iglesias en los días finales de la Comuna. ${ }^{38}$ Sin embargo, la vida pública de Bové como líder sindical de los hiladores de algodón locales había comenzado antes de la consolidación del grupo bakuninista barcelonés. Y, por supuesto, antes de la llegada desde el Midi francés de los pocos o muchos Communards que trataron de resguardarse cruzando la frontera durante el invierno y la primavera de 1871 .

Bové había capitaneado ya una huelga general algodonera en la Barcelona de 1869, pocos meses después de la caída de la monarquía borbónica. Una huelga cuyos principales puntos de fricción preludiarían los que, con tanto o más vigor, se repitieron en 1871 en el caso del conflicto con Batlló. En primer lugar, la oposición obrera a la reducción de las tarifas destajistas a raíz de la introducción de mayores máquinas, particularmente en la hilatura de self-acting mules. Y, simultáneamente, la condena obrera de las tentativas de feminización de oficios fabriles tradicionalmente masculinos, caso del gobierno de las spinning mules y de los telares; feminización inseparable de aquella reforma capitalista de la relación entre carga de trabajo e ingreso obrero. ${ }^{39}$

Según el sindicato algodonero, caso de aceptar Batlló la tarifa destajista que el hilador Bové le presentó el 1 de marzo de 1871 «no habrá otro fabricante [en Barcelona] que lo pague peor que los señores Batlló Hermanos». Las self-acting mules para hilar algodón de Batlló alcanzaban los 1.000 husos o más por máquina, el doble de lo habitual en la hilatura catalana de entonces, de lo que Bové deducía que «atendida la mayor escala con que fabrican los hermanos Batlló pueden muy bien

37 Antonio López Estudillo, «El anarquismo español...», p. 86; Josep Termes, Anarquismo y sindicalismo..., p. 183; La Federación (Barcelona), 12 de Diciembre de 1870.

${ }^{38}$ La Federación (Barcelona), 28 de Mayo de 1871, p. 3 («Nuestro compañero Clemente Bobé continua preso. Las gestiones para sacarlo bajo fianza continuan con una lentitud pasmosa...»); Miguel Izard, Industrialización y obrerismo..., p. 115; Josep Termes, Anarquismo y sindicalismo..., pp. 139-140 (y nota 5).

${ }^{39}$ Sobre la huelga algodonera de 1869 y el liderazgo en ella del hilador Bové: Albert Garcia Balañà, «"Ya no existe Partido Progresista en Barcelona”. Experiencia social y protesta obrera en la insurrección republicana de 1869», HISPANIA Revista Española de Historia, 230 (2008), pp. 735-759, pp. 742-756. 
satisfacer la mano de obra a precios más subidos con más ganancia». ${ }^{40}$ Lo que ocurría era, por supuesto, lo contrario, y algo parecía tener que ver en ello el hecho de que «de seiscientos a setecientos obreros que hay ocupados en la fábrica Batlló son hombres o niños apenas unos cincuenta». En los prolegómenos de la huelga, a finales de febrero, las Tres Clases de Vapor «de Barcelona y contornos» circularon una hoja volante «para ilustrar al público acerca de cómo exprimen el trabajo colectivo de unos cuantos centenares de pobres mujeres los señores Batlló Hermanos dentro de su castillo feudal».$^{41}$ Desde el primer día los equipos destajistas habían sido parcialmente feminizados en la hilatura de selfacting mules de Batlló. Bové y las Tres Clases habían condenado públicamente el nuevo modelo laboral - «sólo tienen obreras para "quitarles" con más desenfado tres, cuatro y a veces más libras por cada pesada de 40 o 50 libras» - ya en la primavera de 1870, cuando la fábrica había abierto sus puertas. Habían lamentado también la práctica ausencia de tejedores masculinos («en la sección de [telares] mecánicos no se quiere más que mujeres para mejor explotar»), y advertido «a los trabajadores de fuera [de Barcelona] que no vengan a Las Corts porque caerían en las manos de unos negreros y perjudicarían de una manera intolerable a sus hermanos de aquí». ${ }^{42}$

Ambos agravios sindicales, contra la rebaja del precio por output fabricado y contra la sustitución de hombres por mujeres en los equipos de hilatura y tisaje, sobrevolaban la industria algodonera catalana desde la segunda mitad de la década de 1850. En el congreso fundacional de la FRE-AIT, en 1870, Climent Bové había recordado el liderazgo decisivo de la Sociedad de Hiladores en la organización de la primera huelga general obrera en España, durante el verano de 1855, y la posterior repre-

${ }^{40}$ La Federación (Barcelona), 5 de Marzo de 1871, pp. 2-3 («Unión de las Tres Secciones de Vapor... Estadística de precios presentada a los señores Batlló Hermanos»). Sobre las dimensiones y número de husos de las máquinas hiladoras self-acting («selfactinas» en Cataluña) de Batlló Hermanos en 1871: Albert Garcia Balañà, La fabricació de la fàbrica..., pp. 516-517.

${ }^{41}$ La Federación (Barcelona), 26 de Febrero de 1871, pp. 2-3 («Cuadernos del Trabajo. Unión de las Tres Secciones de Vapor: Jornaleros, Hilados y Tejedores Mecánicos de Barcelona y contornos...», Barcelona a 21 de Febrero de 1871).

${ }^{42}$ La Federación (Barcelona), 5 de Junio de 1870, p. 3 («Cuadernos del Trabajo. Sociedad de las Tres Secciones de Vapor...»). También La Federación. Actas del Congreso Obrero (Barcelona), 23 de Junio de 1870, p. 7 (intervención de Climent Bové). 
sión que ello había desencadenado sobre dicho sindicato de oficio fabril. ${ }^{43}$ El recelo de los hombres hiladores a hacerse cargo, con sus equipos de «ayudantes», de más husos de hilar (de más o mayores máquinas) fue una constante en la Cataluña algodonera desde 1860 en adelante. La defensa del precio o tarifa por libra de hilo fabricada por su equipo era la punta del iceberg de toda una cultura de oficio del hilador fabril en tanto que reclutador, organizador y beneficiario del trabajo de sus «ayudantes». El hilador era un «subcontratista interno» en expresión de William Lazonick a propósito de los hiladores fabriles del Lancashire inglés; se reclamaba un «vendedor de hilo» al fabricante según detectó William M. Reddy entre los hiladores franceses de 1848. Una cultura de oficio abrumadoramente masculina, notablemente exclusivista en sus orígenes, y para la cual el respeto a una «tradicional» correlación entre carga de trabajo e ingreso era preferible a cualquier aumento de la productividad $-\mathrm{e}$ incluso del ingreso- que pudiese hacerse a costa de más trabajo (no organizativo) del propio hilador $\mathrm{y}$, pues, de su desvalorización en términos de precio y de autoridad dentro y fuera de la fábrica. ${ }^{44}$ Las raíces de dicha cultura del trabajo se hundían, en Cataluña como en el Lancashire o en la región de Lille-Rouen, en el mundo de talleres y pequeñas fábricas prevapor de las primeras décadas del siglo, una temprana industria atomizada en unidades a menudo poco más que familiares entre las cuales se reclutó la primera generación de hombres hiladores en la mayoría de fábricas mecanizadas catalanas. ${ }^{45}$

Brevemente: una cultura del oficio y del trabajo fabril con rasgos de autonomía - y jerarquía - obrera ajenos a la mayor eficiencia del capital. Y una cultura de oficio - de la «clase» significando todavía el oficio ${ }^{46}$ que, gestada durante la doble década $1835-1855$, seguía muy viva en la

43 La Federación. Actas del Congreso Obrero (Barcelona), 26 de Junio de 1870, p. 10 (más detalles sobre el discurso de Bové en 1870 en Albert Garcia Balañà, La fabricació de la fàbrica..., pp. 511-515).

${ }_{44}$ Presentaciones de dicho argumento y de las evidencias empíricas para la hilatura catalana con máquinas mules: Albert Garcia Balañà, «"Ya no existe Partido Progresista en Barcelona"...», pp. 751-756; Albert Garcia Balañà, «"El verdadero productor”: lenguaje y experiencia...», pp. 229-232. La investigación original, y los paralelismos con el Lancashire y Lille-Rouen, en Albert Garcia Balañà, La fabricació de la fàbrica ..., particularmente pp. 15-55.

45 Albert Garcia Balañà, La fabricació de la fàbrica..., pp. 377-451.

46 Albert Garcia Balañà, «"El verdadero productor”: lenguaje y experiencia...», pp. 221-225. 
Barcelona de la Revolución de 1868. Viva, también, por amenazada. Durante la citada huelga de 1869, Bové y sus hiladores sindicalizados habían sido acusados por los fabricantes de pretender «fijar el número de operarios que debe tener cada máquina y hasta intervenir en la admisión de operarios»; de entrometerse, nada menos, «en el personal y la organización de los establecimientos». ${ }^{47}$ Sobre el prisma fracturado por estos reavivados combates locales se proyectaban las luces y las sombras de la simultánea revolución parisina.

\section{Barcelona, primavera de 1871: republicanismo federal y democracia plebeya}

En su respuesta parlamentaria de 22 de mayo al diputado republicano Lostau, el ministro Sagasta alertó contra «esa nube de extranjeros que vienen... mandados por la que acaba de ser Commune de París», a lo que añadió: «sin duda en correspondencia con otras, que aunque tienen otro nombre todo el mundo las conoce muy bien». ¿A qué «otras» Comunas o poderes municipales aludía el dardo de Sagasta, lanzado contra una de las pocas voces obreras del Parlamento español, la del federal catalán Lostau, que en la misma sesión había proclamado: «soy de la Asociación Internacional de Trabajadores»? ${ }^{48}$

Sin duda alguna, a la Diputación Provincial de Barcelona, la más importante institución política gobernada en España por el Partido Republicano Democrático Federal (PRDF) desde la revolución antiborbónica de 1868. Los candidatos republicano-federales habían obtenido la mayoría (simple) en la Diputación de Barcelona en las elecciones celebradas en marzo de 1871, las primeras por sufragio universal masculino. Y las tensiones con el gobierno monárquico en Madrid no habían cesado desde entonces, bajo la doble sombra de la huelga y movilización obrera en Barcelona y de la Comuna en París. Entre el 19 y el 27 de mayo de 1871, durante los días de la represión contra las Tres Clases de Vapor en Barcelona, y exactamente durante el ataque final de Versalles sobre París, el gobierno ocupó militarmente las principales sedes de la Diputación de

47 Citado en Albert Garcia Balañà, «"Ya no existe Partido Progresista en Barcelona"...», p. 748 .

${ }^{48}$ DSC/C, Legislatura de 1871, Sesión de 22 de Mayo de 1871, pp. 1.002 (Sagasta y las «otras» Comunas) y 999 (Lostau y la AIT). 
Barcelona, hostigó policialmente a sus cargos republicanos, e inició la destitución colectiva y el procesamiento judicial de casi todos ellos.

En otras palabras: el gobierno español usó la Comuna, su imagen de insurrección popular finalmente y «felizmente» derrotada, para legitimar su simultánea ofensiva política y policial contra el sindicalismo de oficio y el republicanismo más radicalmente democrático en la Barcelona de 1871. La presencia de la AIT y de sus redes internacionalistas en el París Communard y en la Barcelona post-1868 resultaba la mejor de las coartadas para fabricar dicha justificación de la represión. Pero el verdadero objetivo gubernamental era desacreditar y debilitar un vínculo entre sindicalismo de oficio y republicanismo democrático que, paradójicamente, tenía poco que ver con el sindicalismo «antipolítico» del temprano núcleo bakuninista barcelonés, y cuya génesis era anterior a 18691870. Porque fue precisamente la combinación de la radicalización de la huelga de Batlló con la victoria electoral republicana en Barcelona, en los días finales de marzo del 71, lo que encendió todas las alarmas patricias y progubernamentales. Ciertamente, con París al fondo, potencial espejo.

La prensa monárquica fantaseaba a principios de abril con que «se esperan grandes trastornos por parte de los republicanos en Barcelona» ${ }^{49}$, obvia contribución a la doble represión que estaba por venir de la mano del nuevo gobernador civil, Bernardo Iglesias. Nuevo gobernador que llegó a la ciudad pocos días después de la victoria republicana y con el apoyo de las élites locales afines a la monarquía de Amadeo, quienes - en palabras epistolares de uno de sus miembros - «siempre habían pensado que una vez sentado el Rey al trono ya no se permitirían ni reuniones ni clubs, ni centros ni directorios ni Republicanos, ni anuncios insolentes y amenazadores por las esquinas ni más predicaciones antisociales». ${ }^{50}$ Que ello aún no hubiese ocurrido explicaba el vigor de la huelga obrera y el masivo voto popular para los republicanos federales, las dos caras de una misma moneda según dicha fuente. Otro de los informantes en privado de Víctor Balaguer resultó todavía más explícito en su énfasis en dicha conexión:

49 La Iberia (Madrid), 11 de Abril de 1871, p. 3; la misma alarma pero expresada con mucha más ironía y, por consiguiente, realismo, en La Flaca (Barcelona), 2 de Abril de 1871 (n. ${ }^{\circ} 81$ ), p. 322 («Lo delgado de la soga»).

50 BVB, Epistolario de Víctor Balaguer, 7102901: carta sin firmar a Víctor Balaguer (Barcelona, ?? de Abril de 1871). 
«Este hecho [la victoria del PRDF en las elecciones a la Diputación] revela claramente la imposibilidad de marchar con el sufragio universal del cual sólo hace uso la clase proletaria para subvertir el orden social en términos de imponer la más dura tiranía[,] atacando de una manera abominable la libertad del individuo como ayer ha sucedido con las infelices mugeres [sic] y pobres obreros que en pleno uso de su derecho iban espontáneamente a trabajar a la fábrica de los señores Batlló[,] que ha quedado cerrada y dada de baja en las oficinas de recaudación de contribuciones emigrando sus dueños al extranjero.» 51

Los vínculos entre trabajadores manuales y republicanismo político eran varios y muy visibles en la Barcelona de 1871 (y no sólo en ella). Los candidatos republicano-federales arrasaron en las principales ciudades catalanas en las elecciones del 20 al 23 de marzo. Por vez primera el censo electoral en la provincia de Barcelona se disparó hasta los más de 180.000 hombres mayores de 25 años - consecuencia de la ley electoral de sufragio universal masculino nacida de la nueva Constitución de 1869-, de los cuales votaron casi 70.000. Los republicanos vencieron con claridad en la ciudad de Barcelona, llevándose 9 de sus 14 distritos electorales. ${ }^{52}$ Desde principios de abril iba a presidir la Diputación Provincial de Barcelona Josep A. Clavé, republicano histórico que años atrás había trabajado como tornero mecánico. Para un grupo de alarmados informantes que pretendían llegar a Sagasta vía Balaguer, la nueva Diputación estaba «compuesta de lo peor de la sociedad y presidida por un cantador de café». ${ }^{53}$ Para otro de sus corresponsales barceloneses, en carta fechada el 4 de abril, «en este momento se está eligiendo presidente de la Diputación provincial, que recaerá en un republicano cuyo nombre avergüenza a Barcelona». ${ }^{54}$ La enorme reputación popular de Clavé procedía

${ }^{51}$ BVB, Epistolario de Víctor Balaguer, 7101208: carta de Antonio Castell de Pons a Víctor Balaguer (Barcelona, 28 de Marzo de 1871).

52 Borja de Riquer, «La Diputació revolucionària: 1868-1874», en Borja de Riquer (dir.), Història de la Diputació de Barcelona. Vol. I: 1812-1898, Diputació de Barcelona, Barcelona, 1987, pp. 214-215; Marició Janué i Miret, Els polítics en temps de revolució. La vida política a Barcelona durant el Sexenni revolucionari, Eumo Editorial, Vic, 2002, pp. 95-96.

${ }^{53}$ BVB, Epistolario de Víctor Balaguer, carta con varias firmas no identificables a Víctor Balaguer (Barcelona, 19 de Abril de 1871) [acompaña a la carta 7101404].

54 BVB, Epistolario de Víctor Balaguer, 7101278: carta de Fernando Puig a Víctor Balaguer (Barcelona, 4 de Abril de 1871). 
de su condición de «músico-obrero» desde los años cuarenta, fundador y promotor en España de coros obreros, los «Cors d'en Clavé» o Coros de Clavé, y primer adaptador hispano de La Marseillese. De ahí lo de «cantador de café» al frente de «lo peor de la sociedad». Represaliado repetidamente por gobiernos monárquicos, Clavé había concebido sus coros como espacios de sociabilidad y educación obrera al servicio de una política interclasista con protagonistas plebeyos (como él mismo). ${ }^{55}$ Durante los primeros días de la Revolución de 1868 Clavé había exhortado a los sindicatos de oficio reunidos en Barcelona a dar su apoyo público al naciente PRDF, y a desoir todo argumento «antipolítico». ${ }^{56}$

La operación de sustitución del gobernador Corcuera («el que menos vale y el que más ha mimado a la gente de gresca» según un inquieto testigo monárquico ${ }^{57}$ ) por el nuevo gobernador, Bernardo Iglesias, en los primeros días de abril, demuestra la aceleración política que desencadenó la superposición de la victoria republicana con la huelga y pulso sindical a propósito de Batlló. Y desvela el rol fundamental que en el golpe de timón hacia una política gubernamental de mayor dureza jugaron las élites amadeístas de la ciudad. El archivo personal de Víctor Balaguer permite matizar, rectificar incluso, la imagen de un Sagasta todopoderoso en Gobernación durante la primavera de 1871, marcando el paso de la represión contra la diáspora Communard y las redes transnacionales de la AIT con independencia de los escenarios y los actores locales. ${ }^{58}$

Víctor Balaguer estuvo en contacto constante con Bernardo Iglesias, entonces en el consulado de Lisboa, desde antes de la victoria electoral republicana..$^{59} \mathrm{Y}$ fue la intervención de Balaguer la que finalmente decantó el reemplazo de Corcuera por Iglesias entre el 2 y el 3 de abril, los mis-

55 Sobre Josep A. Clavé, véase Albert Garcia Balañà, «Ordre industrial i transformació cultural a la Catalunya de mitjan segle XIX: a propòsit de Josep Anselm Clavé i l'associacionisme coral», Recerques, 33 (1996), pp. 103-134. Clavé fue el candidato que obtuvo más votos en la ciudad de Barcelona en marzo de 1871: El Telégrafo (Barcelona), 24 de Marzo de 1871, pp. 1.922-1.923.

${ }^{56}$ La Vanguardia. Periódico Republicano Federalista [dirigido por J. A. Clavé] (Barcelona), 18 de Diciembre de 1868 (n. ${ }^{\circ} 8$ ), pp. 2-3 («El Congreso de Obreros»).

57 BVB, Epistolario de Víctor Balaguer, 7101278: carta de Fernando Puig a Víctor Balaguer (Barcelona, 4 de Abril de 1871) [el subrayado en el original].

58 Imgen que no ha abandonado la visión del personaje. Véase José Ramón Milán García, Sagasta o el arte de hacer política, Biblioteca Nueva, Madrid, 2001, pp. 179-182 y 218-219.

59 BVB, Epistolario de Víctor Balaguer, 7101155 y 7101234: cartas de Bernardo Iglesias a Víctor Balaguer (Lisboa, 21 de Marzo de 1871 y 30 de Marzo de 1871). 
mos días en los que Balaguer tuvo alarmadas noticias del resultado pormenorizado del escrutinio electoral ${ }^{60}$ En el interín arreciaron las cartas a Balaguer desde Barcelona urgiéndole el relevo del legalista Corcuera y el regreso del expeditivo Iglesias, cuyo paso por el Gobierno Civil barcelonés en los agitados días del otoño de 1869 e invierno de 1870 permanecía muy vivo en la memoria patricia local. «La prudencia y la energía, o sea la manzana en una mano y el palo en la otra, si no gusta lo primero debe gustar lo segundo - le decía el Progresista Carbonell a Balaguer abogando por las cualidades de Iglesias - ; y si así no sucede, créame amigo, la cosa se la lleva el diablo.» 61

El 18 de abril, tras tomar posesión del Gobierno Civil, Iglesias le confesaba a Balaguer: «Me recibieron admirablemente y yo estoy muy satisfecho. Siento no haber venido 15 días antes para haber evitado la catástrofe electoral, que tan fácilmente pudo evitarse.» ${ }^{62} \mathrm{Y}$ a los pocos días Balaguer recibía otra de las muchas cartas barcelonesas de entonces en la que varios firmantes celebraban el retorno de Iglesias:

«...dicho Sr. Iglesias es el Ángel Tutelar de la ciudad, y con su firmeza va arraigando el orden hermanado con la libertad, y rebaja la autoridad sobre las masas de estos tres o cuatro cientos alborotadores, pinchos y ladrones que tenían la ciudad amedrentada a semejanza de lo de París[,] y dependía la quietud o el desorden de su albedrío, porque hasta ahora la Autoridad Civil ha sido nula o con ellos convenida con grande escán-

60 BVB, Epistolario de Víctor Balaguer, 7101273: carta de Bernardo Iglesias a Víctor Balaguer (Lisboa, 4 de Abril de 1871: «Víctor querido: anoche a las 12 recibí su interesante telegrama. Gracias mil y mil y mil. Tan pronto como Sagasta me lo diga emprenderé mi viaje; y a nuestra vista hablaremos de cien y cien cosas que nos conviene tratar a fondo... »); 7101259: carta de Daniel Carbonell y Jover a Víctor Balaguer (Barcelona, 3 de Abril de 1871).

61 BVB, Epistolario de Víctor Balaguer, 7101259: carta de Daniel Carbonell y Jover a Víctor Balaguer (Barcelona, 3 de Abril de 1871); también 7101254: carta de Francisco Soler y Matas a Víctor Balaguer (Barcelona, 2 de Abril de 1871); 7101278: carta de Fernando Puig a Víctor Balaguer (Barcelona, 4 de Abril de 1871). Sobre Bernardo Iglesias y su primer paso por el Gobierno Civil de Barcelona en 1869-1870, que influyó en la insistencia con la que las élites locales lo reclamaron en 1871: Carmelo de Lucas del Ser, «Bernardo Iglesias, el gobernador enviado por Sagasta a Barcelona para frenar el avance del federalismo y de la Internacional», Argutorio, 30 (2013), pp. 83-92, pp. 89-90.

${ }^{62}$ BVB, Epistolario de Víctor Balaguer, 7101387: carta de Bernardo Iglesias a Víctor Balaguer (Barcelona, 18 de Abril de 1871). 
dalo de los ciudadanos, fastidiando completamente a nuestro querido General Gaminde.» 63

El pulso entre un nuevo poder local fruto de la universalización del voto y del federalismo movilizador y municipalista, y el reconstituido poder central y sus significativos apoyos autóctonos, había comenzado. Y resultaba inseparable de la protesta obrera. París servía para hablar de Barcelona. No resulta extraño, pues, que la Diputación presidida por Clavé condenase públicamente - en su sesión del 13 de mayo - al gobernador Iglesias por «perseguir a sociedades obreras con abuso de poder»y por ordenar «detenciones ilegales», y exigiese que Madrid lo destituyese. ${ }^{64}$ Antes, durante los primeros días de mayo, la Diputación había censurado ya a Iglesias por su aval al acuartelamiento de tropas en la parte baja del Palacio provincial y, sobre todo, por bendecir el despliegue de una guarnición permanente de más de medio centenar de soldados en el gran edificio de la Casa de Caridad, institución administrada por la primera. ${ }^{65}$

El crescendo de tensión entre la Diputación de mayoría republicana y el gobernador culminaría pocos días después, entre el 22 y el 24 de mayo, con la ya relatada reapertura gubernativa de la fábrica Batlló - mediante el despliegue armado que ahuyentó a la vigilancia sindical - y la simultánea irrupción de Iglesias en el Palacio de la Diputación, acompañado por la policía, para la incautación de las recientes actas de la corporación y la presentación de una causa criminal contra la mayoría de diputados por «expresiones ofensivas hacia la fuerza pública» y extralimitación de funciones. ${ }^{66}$ Recién había viajado a Madrid una comisión de diputados para reclamar el cese de Iglesias, un paso sin amparo legal pero alimentado por el espíritu de la nueva ley provincial de enero de 1871 que reducía el poder de vigilancia del Gobierno Civil sobre la vida de las diputaciones. Las provocaciones de Iglesias habían surtido efecto:

${ }^{63}$ BVB, Epistolario de Víctor Balaguer, carta con varias firmas no identificables a Víctor Balaguer (Barcelona, 19 de Abril de 1871) [acompaña a la carta 7101404].

64 Arxiu Històric de la Diputació de Barcelona (Barcelona) [en adelante AHDB], Diputació de Barcelona, Acta de la sesión de 13 de Mayo de 1871; y Legajo 1.594.

65 Borja de Riquer, «La Diputació revolucionària...», pp. 215-216; Josep Pich i Mitjana, Federalisme i catalanisme: Valentí Almirall i Llozer (1841-1904), Eumo Editorial, Vic, 2004, pp. 144-146.

66 AHDB, Diputació de Barcelona, Actas de la sesiones de 26 y 27 de Mayo de 1871. 
«Víctor querido - le escribía privadamente Iglesias a Balaguer el 20 de mayo-: mañana con esta carta sale para ésa [Madrid] la comisión nombrada por la Diputación para pedir al Gefe mi inmediata destitución: la componen los dos diputados Simal y Martorell. Son la flor de esta canalla; lo más fino del canasto. [...] De suerte que ya estamos en el lance serio. En la sesión de esta tarde han consumado su obra, aprobado el acta de ayer [19 de mayo]. Viene pues a resultar que ya tengo todo el asidero legal: ya estoy perfectamente dentro de la ley, y por consiguiente en los primeros días de la semana próxima les doy el golpe de maza en medio de la testuz. Ya avisaré de todo. Voy adelante con mi plan; y este desenlace de las cosas de la Diputación va a poner el sello a todo. Ahora principio a divertirme: ya era tiempo.» ${ }^{67}$

El «plan» del gobernador Iglesias bajo tutela de Víctor Balaguer y sus corresponsales barceloneses, y lo que ese «todo» subrayado encerraba, se reveló con toda crudeza durante los últimos días de mayo y los primeros días de junio. Los días de la derrota final de la Comuna parisina. La ocupación militar de la Casa de Caridad bajo control político republicano y emplazada en el distrito obrero del Raval («por ser aquel barrio turbulento convenía establecer una línea estratégica entre la Universidad Nueva y Capuchinas [en las Ramblas]» ${ }^{68}$ ) preparó el doble golpe gubernativo-policial, contra la huelga en Batlló y contra los diputados provinciales republicanos.

Con el Raval obrero tomado por las tropas del Capitán General, Eugenio Gaminde, Iglesias forzó la reapertura de Batlló, acumuló cargos contra La Federación y fabricó las detenciones de Bové y Sentiñón, de las cuales Balaguer estuvo siempre al día a través del correo. ${ }^{69}$ Simultánea-

${ }^{67}$ BVB, Epistolario de Víctor Balaguer, 7101694: carta de Bernardo Iglesias a Víctor Balaguer (Barcelona, 20 de Mayo de 1871) [el subrayado en el original]. La no unanimidad republicana en la sesión de 19 de mayo a propósito de forzar la destitución de Iglesias: Borja de Riquer, «La Diputació revolucionària...», p. 216.

68 AHDB, Diputació de Barcelona, Acta de la sesión de 12 de Mayo de 1871; Marició Janué i Miret, Els polítics en temps de revolució..., p. 96.

69 BVB, Epistolario de Víctor Balaguer, 7101954: carta del vizconde de San Javier a Víctor Balaguer (Barcelona, 12 de Junio de 1871: «...me alegro que tanto a V. como a Sagasta les haya parecido bien lo que hize al denunciar el n. ${ }^{\circ} 92$ de La Federación... La redacción era el núcleo de todas las sociedades de obreros que acudían con fondos y toda clase de medios para la propagación de La Internacional, coacción del trabajo y continuación de las huelgas. Con Iglesias estoy perfectamente unido y me compondré de modo de dar con todos ellos en la cárcel y por la poca seguridad de ésta en el Castillo de Monjuí [sic]. Tendré a V. al corriente de todo.») 
mente, el gobernador presentaba sus cargos contra la mayoría republicana de la Diputación por extralimitarse en sus funciones al poner firma a la exigencia de su destitución como tal. El 30 de mayo Iglesias le encarecía a Balaguer: «Despácheme V. pronto pronto pronto a esta Diputación. Lo necesito mucho también para el trabajo de las elecciones. Apure V. a esos Señores.» ${ }^{70}$ Cinco días después le recordaba: «Tengo pedido a Sagasta por dos veces que obligue a Beranguer a cambiar aquí la Escuadra: me hace suma falta para que el 16 vote en la Barceloneta. [...] También me convendría que viniese bien despachado antes del 16 el expediente de la Diputación para que sea como propongo.» ${ }^{71} \mathrm{Y}$ el 10 de junio un Iglesias exultante besaba los pies de Balaguer, «poeta mío», y no podía sino mandarle «cien abrazos»: «Doy un millón de gracias por todo; no sé cual de las dos cosas me interesa más, si ver la Escuadra dentro del puerto, para que además pueda votar, o ver a los Diputados federales envueltos en los papeles de un escribano. ¡Qué buen rato voy a pasar!»72 Pocos días después, el 19 de junio de 1871, una real orden del Ministerio de Gobernación con la firma de Sagasta suspendía a los 28 diputados provinciales (24 de ellos de la mayoría republicana) que habían firmado la petición de remoción de Iglesias. Suspensión supuestamente provisional e interina, los tribunales no iban a fallar definitivamente sobre dicha causa, y a revocar aquella suspensión, hasta el lejano verano de $1872 .^{73}$

En consecuencia, no iban a ser únicamente Sagasta y los patricios barceloneses quienes invocasen la Comuna aquella primavera, ellos para revestir con una razón mayor el ataque preventivo gubernamental contra la Diputación de mayoría republicana y sus apoyos obreros. Las numerosas muestras de apropiación de la Comuna por parte del federalismo español, incluidas las de aquellas de sus voces que habían ingresado en la AIT (como la de Lostau), deben leerse, también, a la luz de este episodio barcelonés de afirmación doblemente plebeya, sindical y demócrata-republicana, y de su pronta represión. El lenguaje de Francisco Pi i Margall al celebrar el «bello

70 BVB, Epistolario de Víctor Balaguer, 7101760: carta de Bernardo Iglesias a Víctor Balaguer (Barcelona, 30 de Mayo de 1871) [los subrayados en el original].

71 BVB, Epistolario de Víctor Balaguer, 7101821: carta de Bernardo Iglesias a Víctor Balaguer (Barcelona, 5 de Junio de 1871).

72 BVB, Epistolario de Víctor Balaguer, 7101921: carta de Bernardo Iglesias a Víctor Balaguer (Barcelona, 10 de Junio de 1871).

73 Borja de Riquer, «La Diputació revolucionària...», pp. 217-220; Marició Janué i Miret, Els polítics en temps de revolució..., pp. 97-98. 
espectáculo» de «una ciudad [París] que ha sido durante siglos la reina y señora de Francia abogando y peleando por la autonomía de todas las provincias y pueblos de la República», su «yo he creído ver en aquel movimiento el abandono de la tradición jacobina por la de los girondinos» ${ }^{74}$, remite aquí al de los diputados provinciales republicanos en la Barcelona de mayo del 71 al condenar el obstruccionismo y hostigamiento del gobernador Iglesias, «representante del poder central... que se complace en buscar interpretaciones que anulen y maten el espíritu de progreso». ${ }^{75}$

Igualmente, las lamentaciones barcelonesas y republicanas por la suerte final de la Garde Nationale Communard ${ }^{76}$ remiten a una historia más próxima y propia. Una historia de breves pero recientes experiencias autóctonas de poder local democratizador con significativos apoyos populares. De experiencias de inclusión obrera en instituciones como la Milicia Nacional, cuyo último y decisivo capítulo acababa de tener lugar en Barcelona en el otoño de 1869. Entonces sus batallones con masiva presencia obrera y comandancia republicana habían sido vencidos y desarmados por el ejército tras dos días de combates callejeros. Un episodio de aplastamiento militar de la Milicia civil y casi universal, rebautizada como Voluntarios de la Libertad en 1869, que repetía una situación ya vivida en la ciudad en 1842-1843 y 1855-1856. Lo fundamental es que aquella Milicia Nacional había cristalizado, a pesar de su intermitencia, como un espacio de confluencia entre sindicalismo de oficio y republicanismo político, como una experiencia de politización de trabajadores urbanos y de hibridación social de un republicanismo de inspiración mesocrática. ${ }^{77}$ En 1855-1856, por ejemplo, la Milicia Nacional de Barcelona había sido purgada de sus líderes demócrata-republicanos y de sus batallones obreros tras desobedecer éstos la orden del Capitán General de Cataluña de romper por la fuerza la primera huelga general en defensa del derecho de sindicación. ${ }^{78}$ El ataque militar de 1869 contra la Milicia del distrito obrero

74 Francisco Pi y Margall, «Prólogo a Los Comuneros de París de R. de Cala» (1871), reproducido en José Álvarez Junco, La Comuna en España, pp. 136-139, p. 139.

75 AHDB, Legajo 1.594: acuerdo de 13 de Mayo de 1871 solicitando la destitución del gobernador civil de Barcelona (con la firma favorable de 28 diputados provinciales).

${ }^{76}$ Republicanismo barcelonés y suerte de la Garde Nationale Communard: La Campana de Gràcia (Barcelona), 4 de Junio de 1871, p. 2 («La Milícia de París ha sigut ja desarmada y disolta...»); 11 de Junio de 1871, pp. 2 y 4 («L'ordre regna en Varsòvia»).

77 Albert Garcia Balañà, « "El verdadero productor": lenguaje y experiencia...», pp. 241-250.

78 Albert Garcia Balañà, «Patria, plebe y política...», pp. 30-33. 
del Raval se había producido en plena huelga algodonera liderada por el hilador Bové. La derrota de los milicianos había preparado la de los huelguistas (en muchos casos se trataba de los mismos hombres) y había obligado al exilio en 1869-1870 a no pocos líderes republicanos - como Clavé - acusados de instigar una «insurrección republicana» en buena parte fabricada por el gobierno. ${ }^{79}$

Por todo ello, las discusiones que dividieron al republicanismo federal en 1871 a propósito de cómo responder a la presión del gobierno central, acerca de los pros y los contras de la vía insurreccional, no deben leerse, solamente, como el impacto indiscutible de la Comuna en su circulación transeuropea ${ }^{80}$ Deben leerse, ante todo, como el resultado de la proyección del combate y derrota Communard de mayo de 1871 sobre un cristal local largamente labrado. Largamente labrado por una secuencia de reveses político-milicianos para la alianza local entre republicanismo y sindicalismo de oficio cuyos inicios cabe situar, cuando menos, en los años cincuenta. Una secuencia que, en tanto que experiencia compartida, contribuyó a dicha alianza al tiempo que fabricaba condiciones de tensión para disensiones y divisiones futuras. Josep A. Clavé, el «cantador de café» que en 1871 presidía la nueva Diputación republicana, había renunciado ya a la política de insurrección con movilización popular, que descartó tajantemente para hacer frente a la ofensiva política y judicial de mayo y junio. Clavé había pagado con la cárcel o el destierro los derrotados levantamientos milicianos de 1856, 1866 y 1869. Además, este último exilio lo había llevado durante el invierno de 1870 a Marsella y Lyon, donde conoció los círculos que protagonizarían las muy breves Communes del verano del mismo año y de marzo-abril del 71, y cuyo colapso leyó, sin duda, a la luz de su dilatada experiencia española. ${ }^{81}$ Uno de los corresponsales barceloneses de Víctor Balaguer intuyó, satisfecho, el po-

79 Huelga, Milicia Nacional e «insurrección republicana» en la Barcelona de 1869: Albert Garcia Balañà, «"Ya no existe Partido Progresista en Barcelona”...», pp. 740-747.

${ }^{80}$ Una lectura en tal dirección para el conjunto del republicanismo federal español en 1871, por otra parte enormemente lúcida, en C. A. M. Hennessy, The Federal Republic in Spain..., pp. 145-153.

81 Arxiu Nacional de Catalunya (Sant Cugat del Vallès, Barcelona), Fondo Josep Anselm Clavé, ANC1-700-T-59: carta de Josep A. Clavé a Isabel y Áurea (Marsella, 18 de Noviembre de 1869); ANC1-700-T-64: carta de Josep A. Clavé a Isabel y Áurea (Lyon, 11 de Enero de 1870). Las discusiones sobre la vía insurreccional en el seno del republicanismo federal en la Barcelona de 1870-1871: La Campana de Gràcia (Barcelona), 11 de Junio de 1871, pp. 1-2; Josep Pich i Mitjana, Federalisme i catalanisme..., pp. 140-144. 
der divisor de este cruce de experiencias «insurreccionales», socio-territorial y generacionalmente heterogéneas, en la Barcelona republicana de 1871: «Ayer [22 de junio de 1871] fueron proclamados por la junta de escrutinio los tres diputados monárquicos [a Cortes por Barcelona]. Gracias al ejército, la marina, autoridades y esfuerzo de un corto número de amigos pudo ganarse. Los federales anduvieron retraídos. Creo que la Internacional es para ellos la manzana de la discordia.» ${ }^{82}$

$$
* \quad * \quad *
$$

En 1889 Batlló Hermanos cerró definitivamente las puertas de su gran fábrica barcelonesa tras apenas dos décadas de actividad. Lo hizo, según el semanario patronal Industria e Invenciones, debido a «la serie inacabable de tumultuosas huelgas que han privado de asentar sobre sólidas y racionales bases la organización del trabajo». ${ }^{83} \mathrm{El}$ enorme edificio del Ensanche había sido escenario de una repetida y muy visible conflictividad laboral desde 1871. Una gran huelga de tejedores durante los meses finales de la Primera República, en 1874; otra muerte violenta en 1882, la del director de la sección de tejidos, tras un cisma en la sección de Les Corts de las Tres Clases de Vapor que reforzó las posiciones «antipolíticas»; una nueva oleada de protestas obreras durante la crisis algodonera de $1885-1886 .{ }^{84} \mathrm{Y}$ la culminación en forma de «bomba» o «enorme detonación de un petardo» en la planta noble de la vivienda de Batlló, en el cruce de Rambla de Catalunya con Ronda Universidad, la tarde del 17 de enero de 1889.85 Batlló Hermanos se convirtió, desde 1871, en la bestia negra de un sindicalismo algodonero catalán crecientemente radicalizado, menos por las influencias forasteras y más por el reducidísimo margen de maniobra, institucionalizada, del temprano sindicalismo de oficio fabril. Sindicalismo de oficio de tradición «política» - o «apolítica» como vía hacia la reforma legal y social - en origen, durante el tercio central del si-

${ }^{82}$ BVB, Epistolario de Víctor Balaguer, 7102113: carta de Federico Pons a Víctor Balaguer (Barcelona, 23 de Junio de 1871).

83 Industria e Invenciones (Barcelona), 1 de Junio de 1889 (XI/22), pp. 237-238.

${ }^{84}$ Sobre la conflictiva coyuntura de 1881-1882 en Batlló y el alejamiento de las Tres Clases de Les Corts con respecto a la dirección «política» del sindicato: Miguel Izard, Industrialización y obrerismo..., pp. 138-146 y 144-146.

${ }^{85}$ La Vanguardia (Barcelona), 18 de Enero de 1889, pp. 2-3 («El petardo de ayer»). 
glo XIX. ${ }^{86}$ También a propósito de ello 1871 puede tomarse como un hito en el calendario, un momento de aceleración entre un tiempo pretérito que no acababa de morir y un tiempo nuevo que no acababa de nacer.

Precisamente la mezcla entre lo viejo y lo nuevo, el grado de lo uno y de lo otro, viene marcando la renovación historiográfica sobre la Comuna misma. Roberto Ceamanos acaba de publicar el más completo balance para el lector en castellano. ${ }^{87}$ Así, y a modo de ejemplo, si Jacques Rougerie ha insistido en su tesis del trabajador Communard como alguien todavía más cercano a la tradición sindical-corporativa de 1848 que al proletario industrial y socialista de 1890 , Roger Gould ha señalado, en sentido contrario, la transformación urbana del París del Segundo Imperio, y las nuevas solidaridades vecinales y comunitarias alumbradas por la expulsión hacia la periferia de las familias trabajadoras, como factor clave en la revolución y resistencia de $1871 .^{88}$

De un modo semejante, este artículo ha tratado de iluminar dinámicas locales de continuidad y cambio que mediaron en la recepción de la Comuna en España. Ha rastreado un doble y específico conflicto en el que se desplegó su condena y también su celebración, aquella misma primavera de 1871 en la ciudad de Barcelona. Si el patriciado barcelonés empujó a Sagasta a culpar a agentes Communards de la emblemática huelga contra Batlló de marzo-mayo del 71 fue porque, con ello, podía desacreditar y barrer a un arraigado sindicalismo de oficio algodonero que entonces acumulaba una larga generación de presencia y política ciudadana. Si, simultáneamente, presentó a los republicano-federales del nuevo PRDF, votados masivamente en la Barcelona de finales de marzo del 71, como cómplices del París federal, fue porque trataba de matar tres pájaros de un tiro: legitimaba el hostigamiento policial y judicial contra la Diputación republicana, que iba a encarnar su deseado gobernador Iglesias; reforzaba aquella tesis de la penetración Communard, ahora a través del añejo

${ }^{86}$ Mi presentación detallada de este tránsito sindical y de sus causas políticas, y de 1868-1874 como tiempo clave, en Albert Garcia Balañà, «Trabajo industrial y política laboral en la formación del Estado liberal: una visión desde Cataluña (1842-1902)», en Salvador Calatayud, Jesús Millán y M. ${ }^{a}$ Cruz Romeo, Estado y periferias en la España del siglo XIX. Nuevos enfoques, PUV, València, 2009, pp. 263-313.

87 Roberto Ceamanos, La Comuna de París (1871), Los Libros de la Catarata, Madrid, 2014, pp. 152-169.

88 Jacques Rougerie, Paris insurgé. La Commune de 1871, Gallimard, París, 2006 [1995]; Roger Gould, Insurgent Identities: Class, Community and Protest in Paris from 1848 to the Commune, Chicago University Press, Chicago, 1995. 
vínculo entre sindicalismo algodonero y tradición demócrata-republicana; e introducía, en las filas republicanas, «la manzana de la discordia» de la AIT y de la política insurreccional, pues convocaba todas las lecciones de la derrotada Barcelona miliciana de 1869 a través del breve ascenso y la pronta caída del París Communard de 1871.

Las condiciones acústicas de la agitada sociedad barcelonesa fabricaron los ecos de la Comuna tanto, o más, de lo que pudieron hacerlo la potencia y procedencia de las voces llegadas desde su exterior. 